\title{
A REVIEW OF THE MEDICINAL PLANTS IN BULGARIA - COLLECTION, STORAGE, AND EXTRACTION TECHNIQUES
}

\author{
POPOVA A ${ }^{1}$, MIHAYLOVA D ${ }^{2}$
}

${ }^{1}$ Department of Catering and Tourism, University of Food Technologies, 26 Maritsa blvd, 4000, Plovdiv, Bulgaria. ${ }^{2}$ Department of Biotechnology, University of Food Technologies, Maritsa blvd, 4000, Plovdiv, Bulgaria. Email: popova_aneta@yahoo.com

Received: 09 December 2017, Revised and Accepted: 14 December 2017

\section{ABSTRACT}

Objective: As old as humankind itself, plants have been used as a source of flavor, food preservatives, natural remedies, and ailments. As a part of human culture, medicinal plants are recognized for their healing properties, and the plant knowledge has successfully been transferred from generations to present days. Since natural ingredients enhance safety, medicinal plants' significance is constantly gaining interest because of the therapeutic phytochemicals that they contain.

Methods and Results: The paper offers summarized information about the collection, storage, and extraction practices used in Bulgaria. A brief information regarding the distribution of the medicinal plants of the Bulgarian dendroflora is provided along with a review of the biological activities possessed. The various applications in the traditional and folk medicine are presented.

Conclusion: Sustainable usage of medicinal plants plays a crucial to their conservation and increased healing potency. Thus, this paper reviews and emphasizes on the optimal collection, harvesting, and extracting approaches of medicinal plants.

Key words: Good agricultural practices, Plant conservation, Postharvest extraction, Storage.

(c) 2018 The Authors. Published by Innovare Academic Sciences Pvt Ltd. This is an open access article under the CC BY license (http://creativecommons. org/licenses/by/4. 0/) DOI: http://dx.doi.org/10.22159/ajpcr.2018.v11i3.22994

\section{INTRODUCTION}

Ancient human is known to have utilized plants as drugs for millennia. Today, several traditional and modern therapies are based on medicinal plants and/or their products. Such plants play an important role in balneotherapy (curing baths made by adding medicinal herbs); aromatherapy (physiological or psychical effects through inhaling essential oils), and also homeopathy. The World Health Organization [1] estimates that around $70 \%$ of populations from many countries are using traditional (folk) medicine to cure various ailments. Rural communities continue to rely on locally produced, some from home gardens, and many from forests, pastures, and other multiple-use habitats, plant-based remedies. Women and elders are the principal harvesters, marketers, and healers.

In recent years, there has been growing interest in alternative therapies and the therapeutic use of natural products, especially those derived from plants [2]. The interestin plant collection and usage is due to several reasons, i.e., conventional medicine can be inefficient, synthetic drugs may cause side effects if incorrectly used, a large portion of the world's population still does not have access to conventional pharmacological treatment, and folk medicine and ecological awareness suggest that "natural" products are harmless. Concerning plant origin remedies, it is important to bear in mind certain conceptual distinctions. Plants can be used as therapeutic resources in several ways. When considered as medicinal plants, they could be used as herbal teas. They can also be used as crude extracts in pharmaceutical preparations, such as tinctures, fluid extracts, powder, and pills. Some researches show that the links between the taste perceptions and the medicinal uses of herbal drugs may be understood as biocultural phenomena rooted in the human physiology and dependent on the individual experiences and culture [3].

Approximately 350,000 higher plants are estimated to exist [4]. Relatively speaking, very few medicinal plants have been studied scientifically. The investigation of natural products is a research field with great potential and is especially important in countries, possessing a great biodiversity, like Bulgaria. The Bulgarian flora comprises 159 families, 906 genera, and 3900 species, of which $12.8 \%$ are endemics, 750 medicinal plants, 300 medicinal plants gathered yearly, and 200 in active use $[5,6]$. Herbal utilization in Bulgaria has a long tradition [7]. This traditional knowledge has been documented during the $19-20^{\text {th }}$ centuries by naturalists, folklorists, physicians, and others [8] and is currently an object of interest for national and foreign scientists [9-13]. More than 70 species of medicinal plants are included in The Red Data Book of Bulgaria and are protected by law. These species are rare for various reasons such as specific requirements for growth areas, in addition to problems in reproduction or slow growth. Some plant species are rare because of unreasonable human actions such as the excessive collection for medicinal and decorative purposes (especially when collecting roots and whole plants).

The objective of this paper is to summarize the available information regarding the collection, storage, and extraction techniques of the medicinal plants used worldwide and particularly in Bulgaria. Medicinal plants have a promising future, and their adequate usage demands a more thorough exploration of harvesting and subsequent handling.

\section{Medicinal plants - diversity}

Bulgaria is a south-eastern European country, where the thousands of years of human activity along with the country's diverse relief, geological features and soil, and the specific microclimatic conditions led to significant diversity of plant species, communities, and natural habitats. In addition, the territory of the country is characterized with extreme wealth of plant species. As in many other countries, in Bulgaria, medicinal plants are growing in wild areas, neighborhoods, and backyards. Around 750 species or $19 \%$ of all plant species in the country are medicinal. Most of them, around $90 \%$ of the species, are wild. The families Asteraceae, Lamiaceae, Rosaceae, Fabaceae, Apiaceae, etc., $[14,15]$ are represented by the greatest number of species. Among 
all identified medicinal plants, $50 \%$ are perennial herbaceous plants, $20 \%$ are annual plants, $25 \%$ are shrubs and trees, and the smallest contribution of $5 \%$ goes to biannual herbaceous plants. On the basis of their distribution, the wild medicinal plants in Bulgaria are divided into five groups (Table 1).

The territory of Bulgaria is subdivided into 20 floristic regions, seven of which are subdivided into subregions [17]. The floristic region of the Rhodopi Mountain is richest - with 148 species or $36.5 \%$ of the Bulgarian dendroflora. The Balkan Range comes second - with 143 (35.2\%), followed by the Black Sea Coast - 121 (29.8\%), Pirin mountain - 117 (28.8\%), the Thracian Lowland - 116 (28.6\%), and Mount Vitosha - 114 species each (28.1\%). The least represented are the regions of Mount Belasitsa - 97 (23.9\%), Sofia region - 90 (22.2\%), and the Valley of the River Mesta - 85 species (20.9\%). The floristic regions rank similarly in the percentage of their medicinal dendroflora to the total number of the Bulgarian dendroflora, varying from $82.2 \%$ (Rhodopi) to $47.2 \%$ (valley of the River Mesta).

Bulgaria is among the European export leaders of medicinal and aromatic plants. More than 250 herbs of 200 plant species are subject to consumption. Around 200 herbs of 140 plant species are subject to export. Every year, the Ministry of Environment and Water issues an order specifying the proper usage of medicinal plants under a special regimen. Bulgaria has a comparatively representative and welldeveloped system of protected areas of various categories: 3 national parks, 11 nature parks, 17 biosphere reserves, and more than 80 further protected areas cover about $4.9 \%$ of Bulgaria's territory. The collection of medicinal plants in national parks and in most other protected areas is basically permitted, but it can be restricted in certain sectors or regions; species-specific restrictions may also apply. The regimen does not administer to medicinal herbs intended for personal use.

In Bulgaria, like in most other countries on the Balkans, the wild harvesting of medicinal and aromatic plants accounts for the vast majority (75-80\%). Only an estimated $20-25 \%$ is sourced from cultivation. The most important cultivated medicinal and aromatic species in Bulgaria are Rosa damascene, Lavandula angustifolia, Mentha spp., Sideritis scardica, Chamomilla recutita, Valeriana officinalis, Coriandrum sativum, Silybum marianum, Melissa officinalis [18].

\section{Active ingredients and application}

The interest of the scientific community in wild plants grows with the establishment of compounds showing biological activity and positive effects on the human body. The involvement of free radicals in the aging process and a number of chronic degenerative diseases such as cancer and cardiovascular diseases has been proven. By enriching the knowledge of plants, as an indispensable source of biologically active components, ways to use natural ingredients in foods expected health effects are being looked for. The value of the medicinal plants lies in the chemical substances that produce a definite physiological action on the human body. Plants contain a variety of free radical scavenging molecules such as phenolic compounds (e.g., phenolic acids, flavonoids, quinones, coumarins, lignans, stilbenes, tannins), nitrogen compounds (alkaloids, amines, betalaines), vitamins, terpenoids (including carotenoids), and some other endogenous metabolites which possess

Table 1: Wild medicinal plants in Bulgaria on the basis of their distribution [16]

\begin{tabular}{ll}
\hline Group & $\begin{array}{l}\text { Conservation status, resources of natural habitats, } \\
\text { and prospects for collection }\end{array}$ \\
\hline I & Species of conservation concern \\
II & Species with very good and good utilization resources \\
III & $\begin{array}{l}\text { Species with distinct distribution but no economic } \\
\text { importance }\end{array}$ \\
V &
\end{tabular}

antioxidant activity [19-21]. In addition to this, plant species consist of compounds with antimicrobial and antitumor activities, antiviral potential, pharmacological activity, etc. [22-25].

For the last three decades, many plants from the Bulgarian traditional medicine were investigated for their biological activity as potential sources of biologically active substances [26-33]. As a result of the conducted studies, the Bulgarian medicinal plants are characterized to content various biologically active compounds, which determine their wide and various applications.

As early as 1928, the Ivan Raev's (traditional healer) method for treating Parkinson's disease with belladonna roots wine decoction achieved world fame. In the following 5 years, Raev's method was tested in many western European clinics. After the efficiency of this healing was proved to excel the efficiency of all other remedies used in the therapy of Parkinson's disease, Raev's method was universally recognized under the name of Cura bulgara (Bulgarian healing). The medicinal plants from the families Asteraceae, Lamiaceae and Poaceae have a most common usage [9]. An original Bulgarian herbal drug, Leucojum aestivum, is used in the long-term treatment of mild and moderate degenerative diseases such as dementia and others of the peripheral nervous system [34]. Extracts of Tribulus terrestris have been used for years in both modern and traditional medicine in the compound treatment of decreased libido, impotence, and climacteric syndrome [35]. Extracts of S. marianum are used in cases of liver diseases and as a liver protectant against poisons [36]. C. recutita is known to neutralize allergies, support digestive system, helpful for chronic gastritis, mouth sores, teething pains, toothaches, abscesses, burns, cuts, dermatitis, open leg sores, rashes, skin disorders, wounds, inflamed joints, ingrown nails, insomnia, migraine headaches, menopausal problems, and tension. $R$. damascene is renowned for its fine fragrance and is commercially grown for rose oil preparation [37]. The flower petals are also sometimes used directly to flavor food or to make tea and are considered safe for human consumption. Rhodiola rosea, which is well cultivated in Bulgaria, stimulates the nervous system, decreases depression, and enhances memory performance. The above-ground parts and rhizomes of Alchemilla mollis are used to regenerate skin epithelium exert an antiinflammatory action because of the contained galotannins, flavonoids, and saponins. Arnica montana, a new promising species, is applied to the skin for pain and swelling associated with bruises, aches, sprains, arthritis, and inflammation [38]. Gentian lutea root has a long history of use as an herbal bitter in the treatment of digestive disorders and is an ingredient of many proprietary medicines. It was considered especially useful in states of exhaustion from chronic disease and in all cases of debility, weakness of the digestive system, and lack of appetite. The decoction or infusion of the aerial parts $S$. scardica is used as antioxidant, anti-inflammatory, antimicrobial, vulnerary, analgesic, carminative, and anti-ulcerative agents because of the chemical components found in it which include flavonoids, iridoids, essential oils, and a wide range of micro- and macronutrients [39]. S. scardica is a popular as a tea in Pirin, Slavyanka, and Rhodope Mountains. The drug is traditionally used in the treatment of the common cold, pharyngitis, hacking cough, and pulmonary emphysema and for irritated throat. The tea is also appropriate for treating chronic kidney disease. Hot water extract of the flowering stems is taken orally for prostate inflammation and prostatic hyperplasia [40]. M. officinalis (lemon balm) has a number of practical applications in medicinal science [41]. In the Bulgarian traditional medicine, the root system of Geranium sanguineum is used as astringent, and because of its anti-inflammatory properties, it is applied in the treatment of diarrhea, gastric-enteric catarrh and dysentery [42]. In Bulgaria, C. officinalis flowers are considered beneficial for reducing inflammation, wound healing, and as an antiseptic, while its infusion is characterized with low toxicity and hypno-sedative properties. Its soothing effect has been used for stomach ulcers and inflammation [43].

\section{General collection rules}

Depending on the plant part being used, medicinal plants ought to be harvested during an optimal period to ensure herbal products 
with good quality and persisting wild population habitat survival. Monograms, pharmacopoeias, reference books, and standards provide detailed information about the appropriate harvest time, bearing in mind the concentration of biologically active substances, which diverges conforming to plant growth stage and development.

The target species collection site density should be defined, and rare or scarce species ought not to be collected. It is notorious that the biologically active constituents' quantitative concentration is altered by plant growth and development and plant material should be collected in a desirable season and period to provide excellent quality for plant source and completed product. The same applies to both non-toxic and poisonous plant ingredients. According to the good agricultural practices for medicinal plants, the optimum collection time is determined regarding the targeted plant parts most contained biologically active constituents (time of day or peak season) passing over the total vegetative yield. Only ecologically non-destructive systems of collection should be employed [44]. Areas with potentially high levels of pesticides or other contaminants (garbage dumps, industrial sites, mine tailings, roadsides, etc.) should at all times be avoided due to the high risk of toxic emissions in taken by plants growing there. When collecting tree roots/bushed, the following rules are applied: The main roots ought not to be cut or dug up; only few of the lateral roots can be located and gathered. The used underground plant parts have to be freed from any adhering soil immediately when collected.

Harvesting time depends principally on weather conditions, and dew, rain, and high humidity should be avoided. No foreign matter, toxic plants or weed are allowed to be blended with the plant material being gathered. If harvested material is wet, it should be transported immediately to an indoor drying facility to prevent any possible deleterious effects due to moisture levels that can promote mold or microbial fermentation. A dry place or a facility inaccessible to livestock and domestic animals should be provided so that the medicinal plants can be stored away from insects, birds, rodents, and other pests. To minimize microbial load, contact with soil should be avoided and all machines, devices, and harvesters ought to be kept clean in consideration of lessening spoliation. Cross-contamination ought to be incessantly avoided. Saws, shears, and other tools which come in contact with the plant during harvesting have to be cleaned up from any excess oils or other pollutants. All tools used in the gathering process ought to be in a decent state (cleaned from previous collecting activity). The plants should be transported in clean and dry conditions; thus, if necessary, large cloths can be used as an interface between the soil and the harvested plant. All containers, ventilated or not, should be stored in dry, protected from pests (rodents, insects, birds, etc.), inaccessible to domestic animals and livestock areas when not in use. In case the collection site is not located in proximity of the processing facilities, it might be mandatory to air-dry or sun-dry the raw material prior to it being transported. The collected material is positioned in baskets or bags or another clean container to facilitate carrying and transportation. In case several plant parts are being harvested, they have to be separately gathered and transported in different tanks [45].

\section{Collection rules in Bulgaria}

The wild collection of medicinal plants has a very long tradition among the majority of the rural population in Bulgaria. Some collectors are still very skilled and have a wide range of knowledge about how to collect, which species are collected for what purpose and what times are most appropriate for collecting the species. Until the early 1990s, large trading companies, such as Bilkocoop and Bulgarcoop, regularly held training courses for medicinal plants collectors. According to Hardalova [46], only $20 \%$ of the medicinal plant species occurring in Bulgaria are not threatened by wild collection, but even the most widespread species can quickly diminish and become vulnerable to mass use. Consequently, the collection must be performed by trained pickers, subject to the rules. As a reaction to this situation, Bulgaria introduced a number of restrictions and prohibitions - issued by the Ministry of Environment and Water - Forestry Act, 1997; Environmental Protection Act, 2002; Biodiversity Act, 2002; Protected Areas Act, 2003 [47-51].
The Bulgarian legislation defines two types of use of medicinal plants in the wild:

1. For personal use: $1-10 \mathrm{~kg}$ fresh herbs, depending on the part of the plant that will be used is permitted to be collected daily.

2. For commercial use: Plant collection in large quantities for profit shall be made only after a license fee is paid and a permit is being issued. The permit is issued to an individual picker or a legal herb processor. The document defines type; allowed parts of the medical plant to be picked - leaf, stalk, flower; region or specific locality; conditions for its conservation; the manner and duration of use; collection tools and hygiene requirements, transport, and storage. When the permit is issued to herb processors, it consists of the names of all the pickers who will work. Plant collection rules are regulated in the Ordinance No. 2 to the Law of Medicinal Plants.

There are 768 medicinal plants in the Bulgarian flora, and 764 are plants of indigenous or adventive origin [51]. The Medicinal Plants Act (2000) covers 739 species of higher plants, $28 \%$ of them arboreal and $63 \%$ of the arboreal plants that can be used as medicinal.

The medicinal dendroflora of Bulgaria is characterized by a high conservation importance: 61 species are under the Protection of the Biodiversity Act. Quota system is applied to 36 species under a special regimen of conservation and use. The list of medicinal plants of the Bulgarian dendroflora could lay a foundation for further phytochemical and resource studies of these species in Bulgaria [52].

In Bulgaria, the plants used in large quantities are lime tree (Tilia sp.) flowers, chamomile (Matricaria chamomilla L.), hawthorn (Crataegus monogyna Jacq.), rosehip (Rosa sp. diversa) berries, blackthorn (Prunus spinosa L.), blackberry, nettle (Urtica dioica L.) leaves and root, bramble (Rubus fruticosus), T. terrestris L., dandelion (Taraxacum officinale Weber), harrow (Ononis spinosa L.), St. John's wort (Hypericum perforatum L.), etc.

The collection begins in February when plant growth is stagnant (Table 2).

At this time of year, underground parts - roots, rhizomes, tubers, and bulbs - are being collected. The roots are dug up and washed quickly with cold water, without being soaked in it. In March and April, barks and buds such as birch bark, white willow buds of poplar, and pine tops are collected. Bunches are collected at the beginning of flowering or at full flowering before forming fruits by cutting off a variable length, depending on the height of the plant. The upper leafy parts of large herbaceous plants such as oregano, St. John's Wort, healing woundwort are cut at 20-30 cm from the top. The entire aboveground portion is cut from small herbaceous plants and subshrubs such as thyme, germander, and lady's mantle.

Fruits and seeds are harvested at different times: Fleshy fruits, such as bilberry, elderberry, wild strawberry, and rose hips, are harvested after their complete maturation; dried fruits - such as fennel, coriander, and dill - immediately before their full maturation, to avoid dispersal of seeds; seeds - such as horse chestnut - just before their full ripening.

The leaves are collected in different period of the development of the different types of plants in the following manner: Large leaves of ivy, plantain, and sumac are collected by rosettes, stems, or branches, with or without handles; small leaves (such as those of red and blueberry) are cut to leafy twigs, dried, and then separated by threshing. Healthy, well-developed, green leaves with no diseases and pests on them should be collected. The young petals, located on the top parts of the plants, should not be harvested.

Nettle leaves, lemon balm, and summer snowflake ought to be collected before flowering; bilberry, plantain, and mallow leaves - during flowering; ordinary birch leaves, dandelion, and coltsfoot - after flowering.

Flowers and inflorescences are collected in spring and summer, at the beginning of flowering or at full bloom. Large flowers like the ones of 
Table 2: Plant collection calendar (foundation "information and nature conservation")

\begin{tabular}{|c|c|c|c|c|c|c|c|c|c|c|c|c|}
\hline $\begin{array}{l}\text { Plant/month } \\
\text { Geranium sanguineum L. }\end{array}$ & Jan & Feb & Mar & April & May & June & July & Aug & $\begin{array}{l}\text { Sep } \\
\text { RR }\end{array}$ & $\begin{array}{l}\text { Oct } \\
\text { RR }\end{array}$ & Nov & Dec \\
\hline Chamomilla recutita $\mathrm{L}$. & & & & & $\mathrm{F}$ & $\mathrm{F}$ & $\mathrm{S}$ & & & & & \\
\hline Tilia sp. & & & & & $\mathrm{F}$ & F; L & F; L & $\mathrm{L}$ & & & & \\
\hline Juniperus communis L. & & & & & & & & FR & FR & & & \\
\hline Origanum vulgare $\mathrm{L}$. & & & & & & S & $\mathrm{S}$ & $\mathrm{S}$ & & & & \\
\hline Euphrasia officinalis L. & & & & & & & $\mathrm{S}$ & S & S & & & \\
\hline Teucrium chamaedrys L. & & & & & & & $\mathrm{S}$ & $S$ & & & & \\
\hline Betonica officinalis L. & & & & & & & $\mathrm{S}$ & $\mathrm{S}$ & S & & RR & $\mathrm{RR}$ \\
\hline Sambucus ebulus L. & & & & & & & FR & FR & RR & $\mathrm{RR}$ & & \\
\hline Prunus spinosa L. & & & $\mathrm{F}$ & $\mathrm{F}$ & & & & FR & FR & & & \\
\hline Sambucus nigra L. & & & & & $\mathrm{F}$ & F; L & $\mathrm{L}$ & FR & FR & & & \\
\hline Rosa sp. diversa & & & & & & & & & FR & FR & & \\
\hline Tribulus terrestris L. & & & & & & & $\mathrm{S}$ & S & $\mathrm{S}$ & & & \\
\hline Betula pendula Roth. & & & $\mathrm{B}$ & $\mathrm{B}$ & & $\mathrm{L}$ & $\mathrm{L}$ & $\mathrm{L}$ & $\mathrm{L}$ & & & \\
\hline & & & BD & $\mathrm{BD}$ & & & & & & & & \\
\hline Salix alba L. & & & & B & $\mathrm{B}$ & $\mathrm{B}$ & & & & & & \\
\hline Crataegus monogyna Jacq. & & & & & $\mathrm{F}$ & $\mathrm{F}$ & $\mathrm{L}$ & $\mathrm{L}$ & FR & FR & & \\
\hline Taraxacum officinale Weber. & & & & $S$ & S; L & S; L & S; L & $\mathrm{RR}$ & $\mathrm{RR}$ & $\mathrm{RR}$ & & \\
\hline \multirow[t]{3}{*}{ Malva sylvestris L. } & & & & & L; F; & $\mathrm{L} ; \mathrm{F}$ & $\mathrm{L}$ & $\mathrm{L} ; \mathrm{F} ;$ & L; F; & & & \\
\hline & & & & & $\mathrm{S}$ & & $\mathrm{F}$; & $\mathrm{S}$ & $\mathrm{S}$ & & & \\
\hline & & & & & & & $\mathrm{S}$ & & & & & \\
\hline Ononis spinosa $\mathrm{L}$. & & & & & & S & $\mathrm{S}$ & S & $\mathrm{RR}$ & $\mathrm{RR}$ & & \\
\hline Aesculus hippocastanumL. & & & & & & & & & FR & FR & & \\
\hline Plantago major L.; Plantago lanceolata L. & & & & & $\mathrm{L}$ & $\mathrm{L}$ & $\mathrm{L}$ & $\mathrm{L}$ & $\mathrm{L}$ & & & \\
\hline Hypericum perforatum L. & & & & & & $\mathrm{S}$ & S & $\mathrm{S}$ & S & & & \\
\hline Melilotus officinalis (L.) Pall. & & & & & & $\mathrm{S}$ & $\mathrm{S}$ & $\mathrm{S}$ & S & & & \\
\hline \multirow[t]{3}{*}{ Urtica dioica $\mathrm{L}$. } & & & & & & & $\mathrm{S}$; & $\mathrm{S}$; & & $\mathrm{RR}$ & $\mathrm{RR}$ & \\
\hline & & & & & & & FR; & FR; & FR; & & & \\
\hline & & & & & & & & $\mathrm{L}$ & $\mathrm{L} ; \mathrm{RR}$ & & & \\
\hline Tanacetumvulgare $\mathrm{L}$ & & & & & & $\mathrm{L}$ & $\mathrm{L}$ & $\mathrm{L}$ & & & & \\
\hline Polygonum hydropiper L. & & & & & & & $\mathrm{L}$ & $\mathrm{L}$ & & & & \\
\hline Erythraea centaurium Pers. & & & & & & $\mathrm{L}$ & $\mathrm{L}$ & & & & & \\
\hline
\end{tabular}

RR: Roots, rhizomes, BT: Bulbs or tubers, L: Leaves, B: Barks, F: Flowers, S: Bunches, SD: Seeds, FR: Fruit, B: Buds

common mallow are gathered one by one, with or without short flower stalks. Colorful baskets, such as the dandelion, daisy, and marigold, are collected one by one with short handles.

\section{Harvesting and drying of plant materials}

After being harvested, most of the medicinal plants still contain a lot of moisture. If not being immediately dried, the plant material will start to deteriorate because all the cells are still alive and functioning. Medicinal plants are considered well dried when they contain 15\% moisture, which cannot evaporate and does not affect its properties. Enzymes are inactive at a temperature of $50^{\circ} \mathrm{C}$ and are being disrupted at a temperature of $70^{\circ} \mathrm{C}$. Not all medicinal plants can be dried at $70^{\circ} \mathrm{C}$ (e.g., essential oil plants). When a certain plant has to be dried at a lower temperature, drying ought to be fast, with good ventilation. In other case, the active substances decrease drastically as this happens in plants containing glycosides and those rich in Vitamin C. Oak barks become darker after drying because tannins oxidase to phlobaphenes. Color changes in dried plants are usually associated with enzymatic activity. The cellular juice and its $\mathrm{pH}$ can influence the color of the dried plant. Plants with neutral $\mathrm{pH}$ hardly ever change their color (e.g., water lily), while those with acidic $\mathrm{pH}$ go darker (e.g., cranberry). Acids which are contained in the cellular juice influence the chlorophyll when the plant is being dried, resulting in a yellow plant. The yellowing of plants can also be caused by the sunlight. This is the reason why medicinal plants should be dried in a place without direct sunlight. Some plants have to be stored for a certain period to become medicinal. An example of that practice is the buckthorn. Its bark should be stored for a year so that the glycosides can transform into glucofrangulin [40].

Buds are harvested with brunches, then left to dry, threshed, and cleaned of impurities. Flowers are being collected at a different time of plant development. For example, chamomile is picked at full flowering while plants such as red cilantro, eater pepper, and hawthorn - before full flowering. Overblown, wilted, withered, or contaminated flowers should not be collected. The flowers are cleaned and dried at $35-40^{\circ} \mathrm{C}$. Leaves are harvested at the time of plant flowering. Eaten, damaged, or contaminated leaves ought not to be collected. Flowers and inflorescences are collected in the following ways: Petals (red peony, mullein, etc.,) are collected by scraping the flower; large flowers (healing marshmallow, common mallow, etc.,) are collected one by one or in groups, with or without short flower stalks; petals and buds (black elderberry, red hawthorn, primrose, lime, blackthorn) are collected by breaking off or cutting clusters; colorful baskets of Asteraceae (dandelion, daisy, coltsfoot, and others) collected one by one with short handles [40].

Leaves from different plants should never be mixed. The leaves are usually dried at $45^{\circ} \mathrm{C}$. Leaves are collected as follows: large leaves (birch, black henbane, plantain, belladonna, foxglove woolly, coltsfoot, datura, etc.,) are collected with or without handles, from the rosettes, stems, or branches; nettle leaves, lemon balm, and mint are collected by cutting leafy stems and subsequent leaves separation; small leaves (cranberry red and blue) are collected by cutting off the leafy twigs and separating the leaves by threshing after drying.

Bunches (leaves, flowers, and stems) are picked at $20 \mathrm{~cm}$ from the top of the plant and dried at $40-70^{\circ} \mathrm{C}$. Storage is advisable in a dark, dry, and airy space.

Roots, rhizomes; bulbs, and tubers are collected either in autumn or early spring. Up to $70 \%$ can be harvested from roots, rhizomes, tubers, and bulbs of species that easily recover (birthwort, dandelion, harrow, lovage, black oman, bracken, window forestry, violet, etc.). Up to $40 \%$ can be harvested from for roots, rhizomes, tubers, and bulbs of species 
with hard recovery resources or those which grow under specific environmental conditions (primrose, meadow, wren, liquorice, etc.).

Fruit and seeds are collected when fully matured and dried at $45-100^{\circ} \mathrm{C}$. Storage is in paper bags.

Barks are dried in the sun with the outer part facing sunlight. After that, drying is completed in a dryer at $70^{\circ} \mathrm{C}$. Barks should be stored in a dry, dark, and airy place. It is best to collect barks, where clearings are planned (birch, pine, willow white oak, hazel, etc.).

\section{Extraction techniques}

Different extraction systems are used to extract components from the plant material. Water [27,19,53,54], methanol [55-58], and ethanol [59] have been widely used. In only a few cases, more than one extravagant or sequential multi-solvent extractions were preferred [58,59]. It has been recognized that the extraction solvent may significantly affect the properties of the extract $[60,61]$. Kratchanova et al. [28] subjected Bulgarian medicinal plants to water and $80 \%$ acetone extractions and performed a comparison in terms of total polyphenols content and antioxidant activity. The authors established a significant influence of the solvent used and recommended an application of at least two extraction procedures.

\section{General extraction methods of medicinal plants}

Different parts of the plant such as bark, leaf, seed, and root could be used in different ways for preparing extracts, depending on the desired properties of the extract. With the use of particular solvents in standard extraction methods, the inactive plant components are being separated from the active ones, which represent the pharmaceutical meaning of extraction. The so-retrieved plant products are intended for external or oral usage only because of the relatively impure liquids, powders, or semi-liquids retrieved by extraction. These include decoctions, infusions, fluid extracts, tinctures, semisolid extracts, and powdered extracts.

\section{Solvent extraction}

Solvent extraction is one of the most widely employed methods for the preparation of flower (fresh or dried) extracts. Before extraction, flower samples are subjected to air-drying or freeze-drying, followed by grinding, milling, or homogenization to reduce sample particle size. Solvent extraction (solid-liquid extraction) involves the process of dissolution (leaching). Leaching is a separation technique that involves removal of soluble solids from a solid mixture by employing a suitable solvent or solvent mixture. Various solvents (methanol, ethanol, hexane, acetone, ethyl acetate, chloroform) are commonly used for extraction (either in the pure form or after dilution with distilled water) [62]. Solvent choice mainly depends on the solubility of the bioactive constituents, safety aspects, and potentials involved for artifact formations [63]. The efficiency of the extraction method is vital to the maintenance of bioactive stability as some of the compounds (mainly those of phenolics) tend to get oxidized and degraded at high temperature or prolonged extraction time $[62,64]$. To ensure an optimal extraction of bioactive compounds, the extraction process is repeated 2-3 times, and the extracts are pooled together $[62,65]$. To prevent the formation of artifacts and degradation or polymerization of phenolic compounds, flower extract should not be stored in the solvent at room temperature or exposed to direct sunlight for a long time duration. Solvent extractions are classified into two methods: Continuous and noncontinuous. In the continuous extraction method (such as percolation, Soxhlet extraction), solvent flows through the sample continuously and the saturated solvent is constantly replaced with a less-saturated solvent. In the noncontinuous method (such as maceration, infusion, decoction), the extraction is stopped when a suitable equilibrium is reached between the solute concentration (inside the flowers and the solvent) unless the solvent needs to be replaced with a new batch of solvent [63].

\section{Percolation}

Percolation is an efficient method that can only be done with dried or powdered herbs. The herb is packed evenly into a funnel which sits in a container, and the menstruum is then poured over the top to slowly percolate through the powdered herb. A percolator is comprised of a wide opening (at the top) to accommodate addition or removal of a sample along with a valve at the bottom, designed to allow outflow of the solvent. Then, the samples are covered by addition of a suitable solvent and are allowed to soak for few hours or overnight $[63,66]$.

\section{Soxhlet extraction}

Soxhlet extraction is a common conventional method used for extracting heat-stable compounds. The advantage of this method is that large amounts of drug can be extracted with a much smaller quantity of solvent. This is tremendously economic in terms of time, energy, and consequently financial inputs. The Soxhlet extractor consists of a distillation flask, an extractor, and a condenser. The solvent in the distillation flask is heated and the resulting vapor is condensed in the condenser. The condensed solvent from the condenser fills into the thimble holder containing the sample that needs to be extracted. When the solution in the extractor reaches the overflow level, a siphon aspirates the solution of the thimble holder and unloads it back into the distillation flask, carrying dissolved solute into the bulk liquid. The solute is left in the distillation flask while the solvent is evaporated, condensed, and passed back into the sample solid bed. This process is repeated 3-5 times or until a complete extraction is achieved [67].

\section{Maceration, infusion, and decoction}

Water is a good extraction medium for proteins, sugars, tannins, mineral salts, alkaloids, and some essential oils. Decoction is only suitable for extracting heat-stable compounds, hard plants materials (e.g., roots and barks) and usually resulted in more oil-soluble compounds compared to maceration and infusion.

Maceration is a technique used in winemaking and has been adopted and widely used in medicinal plants research [68]. Maceration was used in homemade preparation of tonic for along time. The maceration process is considered to be rather slow and sometimes requires occasional or continuous shaking/stirring as it works by molecular diffusion. Occasional shaking ensures dispersal of saturated solution around the particle surface, bringing fresh solvent to the surface of particle for further extraction. After that, the extract is filtered through an appropriate filter or screen $[63,67]$.

Infusion and decoction use the same principle as maceration; both are soaked in the cold/boiled water. The maceration period for infusion is shorter, and the sample is boiled in specified volume of water (e.g., 1:4 or 1:16) for a defined time for decoction, however [69].

An infusion is a dilute solution that contains readily soluble constituents prepared by short period of sample maceration (steeping) in cold/ boiling water. Heat-sensitive compounds are recommended to be extracted by cold water [66].

Infusion (the folk method) is made using tablespoon of fresh/dried herbs per cup of boiled water. The aerial parts are mainly used and steeped for 2-10 min, covered. Common herbal infusions are aromatic plants, including mint, chamomile, lavender, and ginger.

Nourishing herbal infusion (folk method) is produced for a minimum of 4 hours of steeping dried herbs in a 1:10 herb: water ratio. This should extract most of the minerals contained in the plant. Popular nourishing herbal infusions are made from U. dioica, Avena sativa, and Trifolium pratense.

Decoction is the most widely used and popular traditional method for the preparation of aqueous extracts of medicinal plants. It is made by boiling the sample in water for a period of fixed time duration [63]. Leaves, roots, and berries are quite suitable for decoctions. Plant parts are heated for 20-40 min (and sometimes longer) to reach constituent extraction. T. officinale root and Sambucus are a few of the plants considered decoction suitable. 


\section{Tinctures}

Pure alcohol best extracts essential oils, resins, alkaloids, glycosides, organic acids, and chlorophyll. A tincture is an alcohol plant extract, made with the use of variable alcohol percentages. Some folk preparations say to always use $50 \%$ alcohol (equal parts water and alcohol), and others - to use ever clear alcohol, but a minimum of $20 \%$ is required for shelf-stability. The herb and its constituents dictate the alcohol percentage. The long shelf life and dosage control make tinctures desirable and convenient forms of herbal consumption.

Folk method - a cup of fresh plant material is filled in a jar to the top, packing it in well but not too hard (fairy mattress consistency). It is then filled to the top with $50 \%$ alcohol and allowed to steep for 4-6 weeks [70].

\section{Microwave-assisted extraction (MAE)}

MAE is suitable for the recovery of a vast array of compounds and is recognized as a versatile and efficient extraction technique of secondary plant metabolites. A lot of examples suggested that MAE has some considerable merits such as shorter extraction time, higher extraction yield, and less solvent consumption compared to conventional extraction methods. MAE utilizes microwave energy to facilitate partition of analytes from the sample matrix into the solvent [71]. Microwave radiation interacts with dipoles of polar and polarizable materials (e.g., solvents and sample) causes heating near the surface of the materials and heat is transferred by conduction. Dipole rotation of the molecules induced by microwave electromagnetic disrupts hydrogen bonding; enhances the migration of dissolved ions, and promotes solvent penetration into the matrix [72]. In non-polar solvents, poor heating occurs as the energy is transferred by dielectric absorption only [69]. MAE of plant secondary metabolites may be affected by a large variety of factors, such as power and frequency of microwave, duration of microwave radiation, moisture content and particle size of plant samples, type and concentration of solvent, ratio of solid to liquid, extraction temperature, extraction pressure, and number of extraction cycles [73]. MAE was currently regarded as a robust alternative to traditional extraction techniques.

\section{Extraction of essential oils}

Hydrodistillation is the simplest and oldest method for obtaining essential oils from plants [74]. Three types of extraction are known to the essential oil industry when it comes to hydrodistillation: water, direct steam, and water and steam. In this method, samples are packed in a distillation unit with addition of water. Essential oils are liberated from oil glands present in the plant tissues (due to effects of hot water and steam). The vapor mixture of water and oil is condensed when it is carried over to the condenser. From the condenser, the distillate flows into a separator, where the essential oil is separated automatically from the distillate water. While some volatile oils can only be distilled by decomposition (e.g., lemon and orange oil), others (flower petals) contain such a small amount of volatile oil content which cannot be feasibly extracted with the use of commercial methods. In such cases, a bland, odorless oil or fat is spread on thin layer of glass plates where the flower petals are left for a certain period; then repeatedly, the petal layer is replaced with a fresh one assuring the absorbance of fragrance in the fat. This technique, known as enfleurage, is widely used in the manufacturing of pomades and perfumes. Distilling volatile oil in an airless atmosphere is known as destructive distillation. For example, when Pinaceae or Cupressaceae wood or resin is heated airlessly, decomposition occurs, and numerous volatile compounds are extracted leaving a residual mass (charcoal). The condensed volatile matter regularly consists of two layers: one aqueous layer, which comprised of methyl alcohol (wood naphtha) and crude acetic (pyroligneous acid), and one tarry liquid representing pine/juniper tar/etc., depending on the wood used. The yield of such dry distillation reaches $10 \%$ of used wood weight and the process is frequently performed in distilleries where the wood is chipped or ground and ignited quickly. However, there are also other physical methods that are used in conjunction with these methods, such as ultrasound treatments, radiation treatments (ultraviolet, Gamma, or electron beams), supercritical carbon dioxide extraction, and others, which have been found to be beneficial for better extraction of bioactive compounds $[75,76]$.

In summary, nowadays, the interest regarding medicinal plants is steadily growing, and the knowledge of their appropriate collection, storage, and even extraction techniques is of a critical matter. The mission of humankind is not only to survive with the help of nature help but also to preserve and provide natural resources for the future generations.

\section{CONCLUSION}

This research review's purpose is to help the reader understand the different aspects posed by the investigation on the medicinal plant collection, storage, and extraction techniques. During the age of functional foods and healthy lifestyle, plant components are gaining significant importance. Contemporary science has acknowledged their active action, and it has included a range of plant origin drugs in modern pharmacotherapy. There has been much investigation and discussion and the advantages of one generation were passed onto another, which upgraded the old properties, discovered new ones, till nowadays. In every period, every successive century from the development of humanity and advanced civilizations, the healing properties of certain medicinal plants were identified, estimated, and transmitted to the subsequent generations. The unceasing interest in medicinal plants has brought today's processing and usage. In spite of the existence of various recommendation sets for the conservation and sustainable use of medicinal plants, only a small portion of these have achieved adequate protection of medicinal plant resources through conventional conservation in natural reserves and parks. More research and good agricultural practices are required to gain a better understanding of the recommended usage and harvesting and storing of the medicinal plants.

\section{ACKNOWLEDGMENT}

The authors gratefully acknowledge the financial support of the Ministry of Education and Science, grant agreement No. DM 07/2.

\section{AUTHOR CONTRIBUTIONS}

Dasha Mihaylova and Aneta Popova were equally involved in the development of the manusript's framework and gathering of the necessary information. Both authors discussed, drafted and wrote the manuscript.

\section{CONFLICT OF INTEREST}

The authors declare no conflict of interest.

\section{REFERENCES}

1. World Health Organization. WHO monographs on selected medicinal plants. Essent Med Heal Prod Inf Portal 1999;1:183-94.

2. Ekor M. The growing use of herbal medicines: Issues relating to adverse reactions and challenges in monitoring safety. Front Pharmacol 2014; $4: 177$

3. Pieroni A, Torry B. Does the taste matter? Taste and medicinal perceptions associated with five selected herbal drugs among three ethnic groups in West Yorkshire, Northern England. J Ethnobiol Ethnomed 2007;3:21.

4. Heywood VH. Ethnopharmacology, food production, nutrition and biodiversity conservation: Towards a sustainable future for indigenous peoples. J Ethnopharmacol 2011;137:1-15.

5. Hubenov Z. Entomofaunistic diversity of Bulgaria. In: Petrova A, editor. Current State of Bulgarian Biodiversity - Problems and Perspectives. Beron: Bulgarian Bioplatform. Sofia, Dracon; 2005. p. 173-98.

6. Petrova A, Vladimirov V. Red list of Bulgarian vascular plants. Phytol Balcan 2009;15:63-94.

7. Dimitrova D, Raycheva T. Ethnobotany and Modern Agrarian Education in Bulgaria. In: Jubilee Scientific Conference with International Participation, Traditions and Challenges of Agricultural 
Education, Science and Business. Vol. LV(2). Agricultural University, Plovdiv, Scientific Works; 2010. p. 333-8.

8. Kozuharova E, Benbassat N, Getov I. Ethnobotanical records of not yet documented therapeutic effects of some popular Bulgarian medicinal plants. Emir J Food Agric 2014;26:647-51.

9. Ivancheva S, Stantcheva B. Ethnobotanical inventory of medicinal plants in bulgaria. J Ethnopharmacol 2000;69:165-72.

10. Ploetz KL. An Ethnobotanical Study of Wild Herb Use in Bulgaria. MSc Thesis, Michigan; USA: Michigan Technological University; 2000.

11. Kultur S, Sami S. Medicinal plants used in Isperih (Razgrad-Bulgaria) district. Turk J Pharm Sci 2009;6:107-24.

12. De Boer HJ. Local awareness of scarcity and endangerment of medicinal plants in Rusenski Lom Natural Park in Northern Bulgaria. In: Pardo-de-Santayana M, Pieroni A, Puri RK, editors. Ethnobotany in the New Europe. New York/Oxford: Berghahn Books; 2010.

13. Bertsch CA. An Ethnobotanical Survey of the Economic and Cultural Significance of Non-timber Forest Products in the Southwest Rhodope Mountain Region of Bulgaria. MSc Thesis. Michigan; USA: Michigan Technological University; 2011.

14. Genova E, Evstatieva L, Vitkova A, Gussev C, Stoeva T, Peshevski N. Mapping of medicinal plants of the Znepole Floristic Region. In: Tsankov G, editor. Proceedings Scientific Papers Second Balkan Scientific Conference on Study. Vol. 1. Sofia: Conservation and Utilization of Forest Resources; 1996. p. 367-73.

15. Vitkova A, Evstatieva L. Biodiversity of medicinal plants in the Rila National Park. In: Me S, editor. Biological diversity of the Rila National Park. Sofia: Pensoft; 2000. p. 79-116.

16. Evstatieva L, Hardalova R. Diversity and resources of medicinal plants. In: Popov A, Meshinev T, editors. High Mountain Treeless Zone of the Central Balkan National Park, Biological Diversity And Problems of its Conservation. Sofia: BSBCP; 2000. p. 437-66.

17. Jordanov D, Nikolov P, Boichinov A. Fitoterapiya. Bilkolechenie. Sofia: Medicina; 1973.

18. Aneva I. Biodiversity of economically important medicinal plants in Bulgaria - Conservation and sustainable use. In: SEE PhytoChemNet Workshop, Medicinal and Aromatic Plants in South East Europe: Environmental and Socio-Economic Challenges, Plovdiv, Bulgaria: The Role of MAB Reserves; 2013.

19. Cai Y, Sun M, Corke H. Antioxidant activity of betalains from plants of the Amaranthaceae. J Agric Food Chem 2003;51:2288-94

20. Ciz M, Denev P, Kratchanova M, Vasicek O, Ambrozova G, Lojek $\mathrm{A}$, et al. Flavonoids inhibit the respiratory burst of neutrophils in mammals. Oxid Med Cell Longev 2012;2012:181295.

21. Ivancheva S, Nikolova M, Tsvetkova R. Pharmacological activities and biologically active compounds of Bulgarian medicinal plants. Phytochemistry: Advances in Research. Kerala: Signpost; 2006. p. 87-103.

22. Nikolova M. Screening of radical scavenging activity and polyphenol content of Bulgarian plant species. Pharmacognosy Res 2011:3:256-9.

23. Karakas P, Yildirim A, Turker A. Biological screening of various medicinal plant extracts for antibacterial and antitumor activities. Turk J Biol 2012;36:641-52.

24. Todorov D, Hinkov A, Shishkova K, Shishkov S. Antiviral potential of Bulgarian medicinal plants. Phytochem Rev 2014;13:525-38.

25. Ivancheva S, Manolova N, Serkedjieva J, Dimov V, Ivanovska N. Polyphenols from Bulgarian medicinal plants with anti-infectious activity. Basic Life Sci 1992;59:717-28.

26. Ivanova D, Gerova D, Chervenkov T, Yankova T. Polyphenols and antioxidant capacity of Bulgarian medicinal plants. J Ethnopharmacol 2005;96:145-50.

27. Kratchanova M, Denev P, Ciz M, Lojek A, Mihailov A. Evaluation of antioxidant activity of medicinal plants containing polyphenol compounds. Comparison of two extraction systems. Acta Biochim Pol 2010;57:229-34.

28. Ivanov I, Vrancheva R, Marchev A, Petkova N, Aneva I, Denev P, et al. Antioxidant activities and phenolic compounds in Bulgarian Fumaria species. Int J Curr Microbiol Appl Sci 2014:3:296-306.

29. Ivanov I. Polyphenols content and antioxidant activities of Taraxacum officinale F.H. Wigg (dandelion) leaves. Int J Pharm Phytoch Res 2014:6:889-93.

30. Denev P, Kratchanova M, Ciz M, Lojek A, Vasicek O, Blazheva D, et al. Antioxidant, antimicrobial and neutrophil-modulating activities of herb extracts. Acta Biochim Pol 2014;61:359-67.

31. Georgieva L, Mihaylova D. Screening of total phenolic content and radical scavenging capacity of Bulgarian plant species. Int Food Res J $2015 ; 22: 240-5$.
32. Mihaylova D, Ivanova M, Bahchevanska S, Krastanov A. Chemical composition and antioxidant activity of ultrasound-assisted extract of the endemic plant Haberlea rhodopensis Friv. J Food Sci Technol 2015;52:2469-73.

33. Ivancheva S, Stantcheva B. Ethnobotanical inventory of medicinal plants in Bulgaria. J Ethnopharmacol 2000;69:165-72.

34. Kumar G, Raghavan AK, Shivanna N. Phytochemicals having neuroprotective properties from dietary sources and medicinal herbs. Pharm J 2014;7:1-17.

35. Akhtari E, Raisi F, Keshavarz M, Hosseini H, Sohrabvand F, Bioos S, et al. Tribulus terrestris for treatment of sexual dysfunction in women: Randomized double-blind placebo - Controlled study. Daru 2014;22:40.

36. Polyak SJ, Oberlies NH, Pcheur EI, Dahari H, Ferenci P, Pawlotsky JM. Silymarin for hepatitis C virus infection. Antivir Ther 2013;18:141-7.

37. Aslam M, Siddiqui A. Rosa damascena: An overview. Eur J Biomed Pharm Sci 2016;3:432-5.

38. Iannitti T, Morales-Medina JC, Bellavite P, Rottigni V, Palmieri B. Effectiveness and safety of Arnica montana in post-surgical setting, pain and inflammation. Am J Ther 2016;23:e184-97.

39. Tadić V, Bojović D, Arsić I, Dorđević S, Aksentijevic K, Stamenić M, et al. Chemical and antimicrobial evaluation of supercritical and conventional sideritis scardica griseb. Lamiaceae extracts. Molecules 2012;17:2683-703

40. Landzhev I. Encyclopedia na Lechebnite Rasteniq v Bulgaria: Biki, Bolesti, Recepti. Sofia: Trud Publishing House; 2010.

41. Dimkov P. Bylgarska Narodna Medicina (Bulgarian Folk Medicine). Sofia: Astrala; 2001.

42. Petkov V. Syvremenna Fitoterapiq. Sofia: Nauka I Izkustvo; 1982.

43. World Health Organization. WHO Guidelines on good agricultural and collection practices (GACP) for medicinal plants. World Health Organ 2003;99:67-73.

44. National Agricultural Advisory Service. Rukovodstvo za DZP na Medicinski i Aromatichni Rasteniya (Good Agricultural Practices Guidelines for Medicinal and Aromatic Plants); 2013.

45. Hardalova R. The use of medicinal plants in Bulgaria and their protection. In: Newton J, editor. Planta Europaea. Hyères. France. Plantlife: Proceedings of the first European Conference on the Conservation of Wild Plants; 1997. p. 184-7.

46. State Gazette of the Republic of Bulgaria. Forestry Act. Bulgaria: State Gazette of the Republic of Bulgaria; 1997. p. 55.

47. State Gazette of the Republic of Bulgaria. Medicinal Plants Act. Bulgaria: State Gazette of the Republic of Bulgaria; 2000. p. 29.

48. State Gazette of the Republic of Bulgaria. Biodiversity Act. Bulgaria: State Gazette of the Republic of Bulgaria; 2002. p. 77.

49. State Gazette of the Republic of Bulgaria. Environmental Protection Act. Bulgaria: State Gazette of the Republic of Bulgaria; 2002. p. 91.

50. Ch G. Characteristic of wild medicinal plants resources in Bulgaria and their sustainable management. In: Petrova A, editor. Current State of Bulgarian Biodiversity - Problems and Perspectives. Sofia: Bulgarian Bioplatform; 2005. p. 495-508.

51. Tashev A, Tsavkov E. Medicinal plants of the Bulgarian dendroflora. Phytolog Balcan 2008;14:269-78.

52. Zheng W, Wang SY. Antioxidant activity and phenolic compounds in selected herbs. J Agric Food Chem 2001;49:5165-70.

53. Katalinic V, Milos M, Kulisic T, Jukic M. Screening of 70 medicinal plant extracts for antioxidant capacity and total phenols. Food Chem 2006;94:550-7.

54. Kiselova $\mathrm{Y}$, Ivanova $\mathrm{D}$, Chervenkov $\mathrm{T}$, Gerova D, Galunska B, Yankova T. Correlation between the in vitro antioxidant activity and polyphenol content of aqueous extracts from Bulgarian herbs. Phyther Res 2006;20:961-5.

55. Shan B, Cai YZ, Sun M, Corke H. Antioxidant capacity of 26 spice extracts and characterization of their phenolic constituents. J Agric Food Chem 2005;53:7749-59.

56. Wojdylo A, Oszmianski J, Czemerys R. Antioxidant activity and phenolic compounds in 32 selected herbs. Food Chem 2007;105:940-9.

57. Djeridane A, Yousfi M, Nadjemi B, Boutassouna D, Stocker P, Vidal N. Antioxidant activity of some Algerian medicinal plants extracts containing phenolic compounds. Food Chem 2006;97:654-60.

58. Su L, Yin JJ, Charles D, Zhou K, Moore J, Yu L. Total phenolic contents, chelating capacities, and radical-scavenging properties of black peppercorn, nutmeg, rosehip, cinnamon and oregano leaf. Food Chem 2007;100:990-7.

59. Wojcikowski K, Stevenson L, Leach D, Wohlmuth H, Gobe G. Antioxidant capacity of 55 medicinal herbs traditionally used to treat the urinary system: A comparison using a sequential three-solvent extraction process. J Altern Complement Med 2007;13:103-9. 
60. Zhou K, Yu L. Effects of extraction solvent on wheat bran antioxidant activity estimation. LWT Food Sci Technol 2004;37:717-21.

61. Mihaylova D, Bahchevanska S, Toneva V. Examination of the antioxidant activity of Haberlea rhodopensis leaf extracts and their phenolic constituents. J Food Biochem 2013;37:255-61.

62. Dai J, Mumper RJ. Plant phenolics: Extraction, analysis and their antioxidant and anticancer properties. Molecules 2010;15:7313-52.

63. Jones WP, Kinghorn AD. Extraction of Plant Secondary Metabolites. In: Sarker SD, Latif Z, Gray AI, editors. Natural Products Isolation. Methods in Biotechnology. Totowa, NJ: Humana Press; 2005. p. 323-51.

64. Robards K. Strategies for the determination of bioactive phenols in plants, fruit and vegetables. J Chromatogr A 2003;1000:657-91. 67.

65. Stalikas CD. Extraction, separation, and detection methods for phenolic acids and flavonoids. J Sep Sci 2007;30:3268-95.

66. Singh J. Maceration, percolation and infusion techniques for extraction of medicinal and aromatic plants. In: Handa SS, Khanuja SP, Longo G, Rakesh DD, editors. Extraction Technologies for Medicinal And Aromatic Plants. Trieste: International Centre For Science And High Technology; 2008. p. 67-82.

67. Tandon S, Rane S. Decoction and hot continuous extraction techniques. In: Handa SS, Khanuja SP, Longo G, Rakesh DD, editors. Extraction Technologies for Medicinal and Aromatic Plants. Trieste: International Centre For Science And High Technology; 2008. p. 93-106.

68. Prasanth N, Dilip C, Dev KS, Lis A, Saraswathi R. Evaluation of invitro cytotoxic and antioxidant activities of Ipomoea batatas. Int J Pharm Pharm Sci 2010;2:91-2.
69. Handa S. An overview of extraction techniques for medicinal and aromatic plants. In: Handa SS, Khanuja SP, Longo G, Rakesh DD, editors. Extraction Technologies for Medicinal And Aromatic Plants. Trieste: International Centre For Science And High Technology; 2008. p. 21-52.

70. Georgieva A, Garov G, Rangochev K. Bilkite Okolo Nas Sreshtu Bolkite v Nas (The Herbs Around us Against the Aches Inside us. Prescriptions from the Villages Garmen, Debren, Dabnitsa, Ognyanovo and Ribnovo, Gotse Delchev Region). Sofia: Gutenberg Publishing House; 2004. p. 88.

71. Trusheva B, Trunkova D, Bankova V. Different extraction methods of biologically active components from propolis: A preliminary study. Chem Cent J 2007;1:13

72. Kaufmann B, Christen P. Recent extraction techniques for natural products: Microwave-assisted extraction and pressurised solvent extraction. Phytochem Anal 2002;13:105-13

73. Zhang HF, Yang XH, Wang Y. Microwave assisted extraction of secondary metabolites from plants: Current status and future directions. Trends Food Sci Technol 2011;22:672-88.

74. Jose B, Reddy L. Analysis of the essential oils of the stems, leaves and rhizomes of the medicinal plant Costus pictus from Southern India. Int J Pharm Pharm Sci 2010;2:100-1.

75. Tongnuanchan P, Benjakul S. Essential oils: Extraction, bioactivities, and their uses for food preservation. J Food Sci 2014;79:R1231-49.

76. Menon S, Agarwal H, Rajeshkumar S, Kumar SV. Green synthesis of silver nanoparticles using medicinal plant Acalypha indica leaf extracts and its application as an antioxidant and antimicrobial agent against foodborne pathogens. Int J Appl Pharm 2017;9:42-50. 